\title{
Genotyping via Sequence Related Amplified Polymorphism Markers in Fusarium culmorum
}

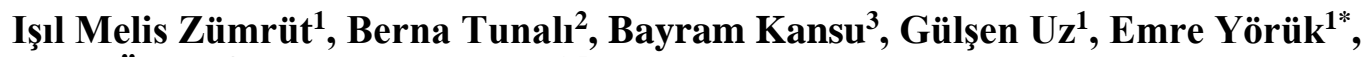 \\ Fatih Ölmez ${ }^{4}$, Ayşegül Sarıkaya ${ }^{1,5}$ \\ ${ }^{1}$ Department of Molecular Biology and Genetics/Faculty of Arts and Science, Yeni Yüzyil University, 34034 Istanbul, Turkey \\ ${ }^{2}$ Department of Plant Pathology/Faculty of Agriculture, Ondokuz, Mayls University, 55100 Samsun, Turkey \\ ${ }^{3}$ Animal and Plant Production Department/Vocational School, Ondokuz. Mayıs University, 55100 Samsun, Turkey \\ ${ }^{4}$ Biotechnology Department/Field Crop Central Research_Institute, 06170 Ankara, Turkey \\ ${ }^{5}$ Department of Medical Biology and Genetics/Medical Faculty, Yeni Yüzyll University, 34034 İstanbul, Turkey
}

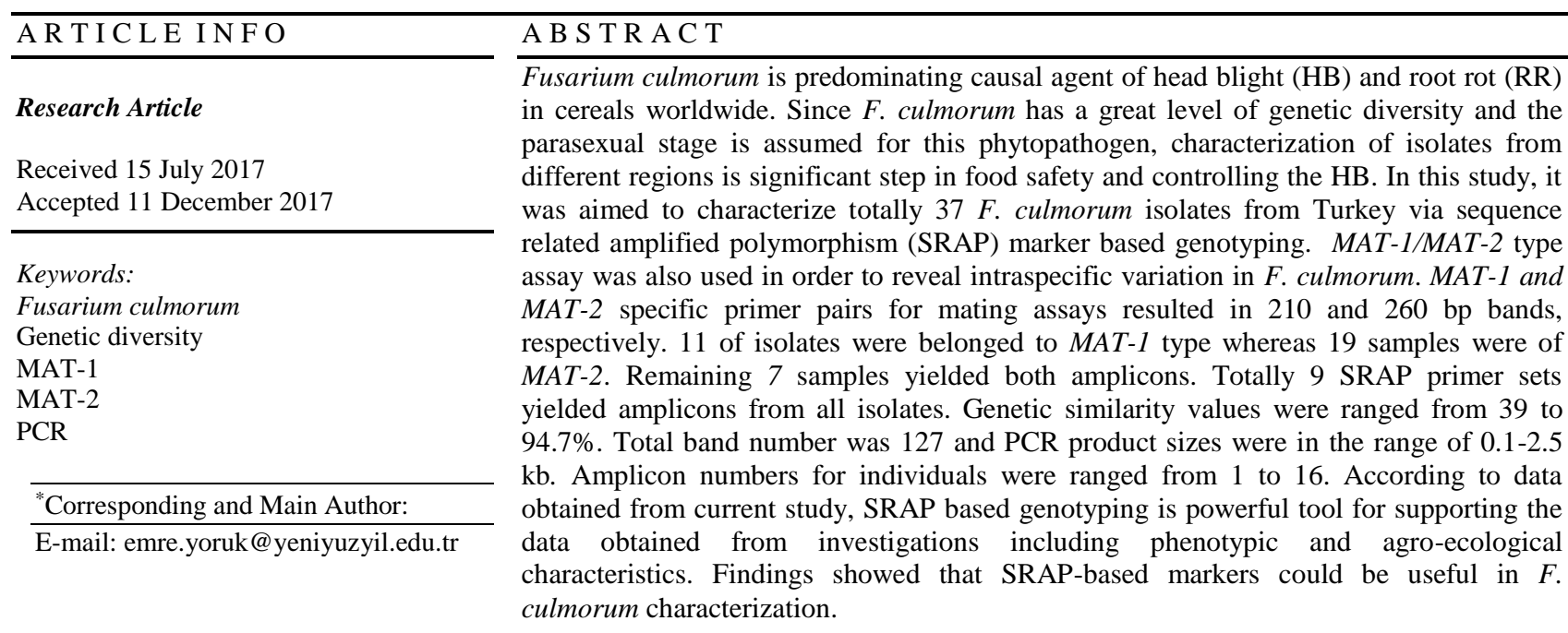

DOI: https://doi.org/10.24925/turjaf.v6i2.145-149.1423

\section{Introduction}

Head blight (HB) and root rot (RR) are diseases in economically important cereals including wheat and barley worldwide. The diseases are caused by more than ten Fusarium species. Fusarium culmorum, a single phylogenetic species, is a major causal agent of $\mathrm{HB}$ in many agro-ecological regions located in West-Asia, Europe and America (Obanor et al., 2010; Pasquali et al., 2016). Diseases caused by $F$. culmorum resulted in severe economic losses due to decrease in crop quality and quantity (Smiley et al., 2005; Miedaner et al., 2008). Moreover, diseased kernels are contaminated with trichothecenes, zearalenon and fusarins of which are harmful to both humans and animals. Chronic and fatal mycotoxicosis are caused by these mycotoxins and estrogenic effects and protein synthesis inhibition are most famous of those (Desjardins and Proctor, 2007). Thus, struggling with $F$. culmorum is crucial in management of HB and RR diseases.
Several strategies are present in order to struggle with adverse effects caused by $F$. culmorum. Usage of disease resistant cereal cultivars, antagonistic and antimicrobial approaches and gene silencing/genetic manipulations are some of them (Arslan and Baykal, 2002; Wisniewska and Kowalczyk, 2005; Scherm et al., 2011). However, these strategies do not provide an effective and global success in disease management. Reliable, stable and precise strategy which can overcome the $F$. culmorum adverse effects is associated with comprehensive characterization of $F$. culmorum populations worldwide. F. culmorum is anamorph species with no known sexual stage. Mating type is controlled via MAT1-1 or MAT1-2 alleles (Kerényi et al., 2004). However, parasexual status is suggested by Miedaner et al. (2001, 2008). This suggestion was also supported by mating type analysis by location of two idiomorphic alleles on a single isolates genome (Obanor et al., 2010, Çepni et al., 2013; Albayrak et al., 2016). 
Detailed characterization of $F$. culmorum is in need of providing powerful disease management worldwide. Polymerase chain reaction (PCR) based genotyping strategies can provide supportive output associated with morphological and phenotypic diversity characteristics.

PCR based DNA marker methods present reliable, reproducible and fast assays in characterization of heterothallic F. culmorum species. Several strategies including random amplified polymorphic DNA, inter simple sequence repeats and simple sequence repeats, have been currently used in $F$. culmorum genotyping (Miedaner et al., 2001; Gurel et al., 2010; Irzykowska et al., 2013; Albayrak et al., 2016). Sequence related amplified polymorphism (SRAP) method uses two primers with nucleotide sequence of conserved coding sites throughout the genomes. The method is powerful tool for genetic mapping and genetic diversity analysis $(\mathrm{Li}$ and Quiros, 2001; Irzykowska et al., 2013; Mahmoud, 2016). Moreover reliable and supportive output can be provided for making association between phenotypic characteristics (aggressiveness, linear growth rate etc.) and genotypes. In this study, characterization of $F$. culmorum isolates from different agro-ecological regions of Turkey is carried out. For this purpose, genotypic assays of mating type differentiation and SRAP based characterization were maintained in this study.

\section{Materials and Methods}

\section{Fungal Material and DNA extraction}

37 F. culmorum isolates obtained from diseased wheat and barley kernels of different regions in Turkey were used in this study (Table 1). Each isolates were identified at species level via morhological characteristics and species-specific SCAR markers formerly by Yörük et al. (2016). Fungal isolates were grown at $25^{\circ} \mathrm{C}$ on Czapek Dox Agar (CDA). 7-day-old cultures were used in extraction of genomic DNA. That was isolated by using slightly modified version of the sodium dodecyl sulphatebased protocol of Niu et al. (2008). Quantitative and qualitative analyzes of genomic DNAs were examined by $1 \%$ agarose gel electrophoresis and spectrophotometer (Shimadzu, Japan). DNAs were photographed via gel visualization system under UV light (Maestrogen, USA).

\section{Mating Type Analysis}

Primer pairs, targeting MAT1-1 specific $\alpha$ box and MAT2 specific HMG box, developed by Kerényi et al. (2004) were used in mating type characterization of $F$. culmorum isolates (Table 2). PCR mixture was conducted on $25 \mu \mathrm{L}$ including $25 \mathrm{ng}$ genomic DNA, 1 X PCR buffer, $2.5 \mathrm{mM} \mathrm{MgCl} 2,0.25 \mathrm{mM}$ of each dNTP's, $0.25 \mu \mathrm{M}$ for each primer, $1 \mathrm{U}$ Taq DNA polymerase (Solis Bio Dyne, Estonia). The cycling conditions were as the same as reported by Kerényi et al. (2004). PCR bands were analyzed on $1.5 \%$ agarose gels as given before.

\section{SRAP Assays}

Totally 9 primer set combinations were formed using 3 forward and 3 reverse primers (see Table 2). PCR mixture was conducted on $25 \mu \mathrm{L}$. The mixture was containing components as follows; $50 \mathrm{ng}$ genomic DNA, $1 \mathrm{X}$ PCR buffer, $2.5 \mathrm{mM} \mathrm{MgCl} 2,0.2 \mathrm{mM}$ of each dNTP's,
$0.4 \mu \mathrm{M}$ for each primer, $1 \mathrm{U}$ Taq DNA polymerase (Solis Bio Dyne, Estonia). The cycling conditions were as the same protocol provided by Zhang et al. (2014). PCR bands were visualized on agarose electrophoresis as described before.

\section{Statistical Analysis}

SRAP bands were scored according to their presence and absence as ' 1 ', and ' 0 ', respectively. A similarity matrix was formed using Nei-Li's coefficient (Nei and Li, 1979). A dendrogram was generated via the unweighted pair group method with arithmetic average algorithm (UPGMA) in MVSP 3.1 software (Kovach, United Kingdom).

\section{Results and Discussion}

The Fusarium culmorum isolates used in this study were characterized by their morphological characteristics. Fungal isolates were successfully grown on CDA medium. Genomic DNAs with high quality $\left(\mathrm{A}_{260 / 280}=\right.$ 1.8) were isolated from 7-day-old cultures in the amount of $0.5-3 \mu \mathrm{g} / \mu \mathrm{L}$.

After DNA extraction, 37 F.culmorum isolates were subjected to mating type analysis. According to the mating type analysis, 11 isolates yielded $210 \mathrm{bp}$ amplicon corresponding to MAT-1 (data not shown), 19 isolates were belonged to MAT-2 type since their mating type analysis resulted in 260 bp (Figure 1). The remaining seven samples corresponded to both MAT-1 and MAT-2 alleles.

Genetic variation was investigated among $37 \mathrm{~F}$. culmorum isolates using Sequence Related Amplified Polymorphism (SRAP) technique. For this purpose, 9 SRAP primer combinations (ME1-EM1, ME1-EM3, ME1-EM6, ME3-EM1, ME3-EM3, ME3-EM6, ME5EM1, ME5-EM3 and ME5-EM6) were used. In SRAP analysis, each primer sets yielded amplicons in all isolates (Figure 2). PCR product sizes were in the range of 0.1-2.5 kb. Totally 114 markers were obtained from 9 primer sets. Minimum and maximum band numbers for individuals were as 1 to 16 , respectively. Even if majority of isolates from related and close agro-ecological regions were coclustered in the same sub-clusters. Some isolates were located with isolates from different regions at same subcluster meaning that heterogeneity was present Turkish Fusarium isolates.

The dendrogram constructed using the SRAP data shows that the isolates to be divided into two divisions (Figure 3). Each cluster also included two sub-divisions. In SRAP analysis, the similarity matrix among 37 isolates of F. culmorum were determined by Nei and Li (1979) coefficient (data not shown). The genetic similarity rate was ranged from a minimum value of $39 \%$ to a maximum value of $94.7 \%$. The highest similarity rate $(94.7 \%)$ was observed between F4 isolate and F12 isolate. Both isolates were originating from Marmara Region. The lowest similarity rate was observed between $F$. culmorum 14-1 isolate and 19F. While F. culmorum 14-1 isolate was obtained from diseased barley kernels in Sivas city, $F$. culmorum 19 isolate of wheat was originated from Eskisehir. 
Table 1 Isolates used in this study

\begin{tabular}{|c|c|c|c|c|c|}
\hline Isolate & Year & Host & Region & Chemotype & Mating type \\
\hline F1 & 2006 & Wheat & Marmara & $\mathrm{DON}+3-\mathrm{AcDON}$ & MAT1-1 \\
\hline $\mathrm{F} 2$ & 2006 & Wheat & Marmara & $\mathrm{DON}+3-\mathrm{AcDON}$ & MAT1-2 \\
\hline F3 & 2006 & Wheat & Konya & $\mathrm{DON}+3-\mathrm{AcDON}$ & MAT1-2 \\
\hline $\mathrm{F} 4$ & 2006 & Wheat & Marmara & $\mathrm{DON}+3-\mathrm{AcDON}$ & MAT1-2 \\
\hline F10 & 2006 & Wheat & Bilecik & $\mathrm{DON}+3-\mathrm{AcDON}$ & MAT1-1 \\
\hline F12 & 2006 & Wheat & Balıkesir & $\mathrm{DON}+3-\mathrm{AcDON}$ & MAT1-2 \\
\hline F14 & 2006 & Wheat & Bilecik & $\mathrm{DON}+3-\mathrm{AcDON}$ & MAT1-2 \\
\hline $\mathrm{F} 15$ & 2006 & Wheat & Sinop & $\mathrm{DON}+3-\mathrm{AcDON}$ & MAT1-1 \\
\hline F16 & 2006 & Wheat & Konya & $\mathrm{DON}+3-\mathrm{AcDON}$ & MAT1-1 \\
\hline F17 & 2006 & Wheat & Konya & $\mathrm{DON}+3-\mathrm{AcDON}$ & MAT1-1 \\
\hline F19 & 2006 & Wheat & Konya & $\mathrm{DON}+3-\mathrm{AcDON}$ & MAT1-1 \\
\hline 09-1TR & 2009 & Wheat & Kastamonu & $\mathrm{DON}+3-\mathrm{ADON}$ & MAT1-1/2 \\
\hline $15-3 \mathrm{TR}$ & 2015 & Barley & Tekirdağ & $\mathrm{DON}+3-\mathrm{ADON}$ & MAT1-2 \\
\hline F20 & 2006 & Wheat & Bilecik & $\mathrm{DON}+3-\mathrm{AcDON}$ & MAT1-2 \\
\hline F21 & 2006 & Wheat & Uşak & $\mathrm{DON}+3-\mathrm{AcDON}$ & MAT1-1 \\
\hline $\mathrm{F} 24$ & 2006 & Wheat & Konya & $\mathrm{DON}+3-\mathrm{AcDON}$ & MAT1-2 \\
\hline $15-4 \mathrm{TR}$ & 2015 & Wheat & Edirne & $\mathrm{DON}+3-\mathrm{ADON}$ & MAT1-2 \\
\hline $17 \mathrm{~F}$ & 2009 & Wheat & Ankara & $\mathrm{DON}+3-\mathrm{AcDON}$ & MAT1-1/2 \\
\hline $18 \mathrm{~F}$ & 2010 & Wheat & Eskişehir & $\mathrm{DON}+3-\mathrm{AcDON}$ & MAT1-1 \\
\hline $19 \mathrm{~F}$ & 2010 & Wheat & Eskişehir & $\mathrm{DON}+3-\mathrm{AcDON}$ & MAT1-1/2 \\
\hline $20 \mathrm{~F}$ & 2011 & Barley & Afyon & $\mathrm{DON}+3-\mathrm{AcDON}$ & MAT1-1/2 \\
\hline 14-1TR & 2014 & Barley & Sivas & $\mathrm{DON}+3-\mathrm{ADON}$ & MAT1-1/2 \\
\hline 14-2TR & 2014 & Wheat & Samsun & $\mathrm{DON}+3-\mathrm{ADON}$ & MAT1-1/2 \\
\hline 15-1TR & 2015 & Wheat & Tekirdağ & $\mathrm{DON}+3-\mathrm{ADON}$ & MAT1-1/2 \\
\hline 14-3TR & 2014 & Wheat & Yozgat & $\mathrm{DON}+3-\mathrm{ADON}$ & MAT1-1 \\
\hline $15-2 \mathrm{TR}$ & 2015 & Wheat & Edirne & $\mathrm{DON}+3-\mathrm{ADON}$ & MAT1-2 \\
\hline $8 \mathrm{~F}$ & 2009 & Wheat & Ankara & $\mathrm{DON}+3-\mathrm{AcDON}$ & MAT1-2 \\
\hline $9 \mathrm{~F}$ & 2008 & Wheat & Isparta & $\mathrm{DON}+3-\mathrm{AcDON}$ & MAT1-1 \\
\hline $10 \mathrm{~F}$ & 2007 & Wheat & Samsun & $\mathrm{DON}+3-\mathrm{AcDON}$ & MAT1-2 \\
\hline $11 \mathrm{~F}$ & 2009 & Wheat & Çorum & $\mathrm{DON}+3-\mathrm{AcDON}$ & MAT1-2 \\
\hline $13 \mathrm{~F}$ & 2008 & Wheat & Konya & $\mathrm{DON}+3-\mathrm{AcDON}$ & MAT1-1 \\
\hline 12-1TR & 2012 & Wheat & Konya & $\mathrm{DON}+3-\mathrm{ADON}$ & MAT1-2 \\
\hline 09-2TR & 2009 & Wheat & Ankara & $\mathrm{DON}+3-\mathrm{ADON}$ & MAT1-2 \\
\hline 14-9TR & 2014 & Barley & Sivas & $\mathrm{DON}+3-\mathrm{ADON}$ & MAT1-2 \\
\hline $12 \mathrm{~F}$ & 2009 & Wheat & Amasya & $\mathrm{DON}+3-\mathrm{AcDON}$ & MAT1-2 \\
\hline 14-8TR & 2014 & Wheat & Amasya & $\mathrm{DON}+3-\mathrm{ADON}$ & MAT1-2 \\
\hline $15-5 \mathrm{TR}$ & 2015 & Wheat & Edirne & $\mathrm{DON}+3-\mathrm{ADON}$ & MAT1-2 \\
\hline
\end{tabular}

Table 2 Primers used this study.

\begin{tabular}{l|lcc}
\hline \multicolumn{1}{c|}{ Primer } & \multicolumn{1}{c}{ 5'-3' sequence } & Target Region & Band size in kb \\
\hline ME1 & TGAGTCCAAACCGGATA & & \\
EM3 & GACTGCGTACGAATTGAC & \multirow{2}{*}{ Conserved exon } & $0.2-2.5$ \\
EM6 & GACTGCGTACGAATTGCA & & \\
ME3 & TGAGTCCAAACCGGAAT & & \multirow{2}{*}{0.21} \\
EM1 & GACTGCGTACGAATTAAT & \multirow{2}{*}{ MAT-1 } & \multirow{2}{*}{0.26} \\
\hline FusALPHAfor & CGCCCTCTKAAYGSCTTCATG & \multirow{2}{*}{ MAT-2 } \\
\hline FusALPHArev & GGARTARACYTTAGCAATYAGGGC & \\
FusHMGfor & CGACCTCCCAAYGCYTACAT & & \\
\hline
\end{tabular}

According to the findings of the dendrogram, the Turkish $F$. culmorum isolates used in the study were clustered according to the geographical regions. In general, isolates from the same agro-ecological regions were co-clustered in the same sub-division. Moreover sub-division II included both wheat and barley phytopathogenic isolates, whereas sub-division I contained just wheat pathogens. Similarly, isolates with collection year between 2006-2009 included in subdivision I, while 2009-2015 isolates were belonged to sub-division II. In mating type analysis, it was also clear that isolates carrying two alleles are replaced in subdivision II. These findings showed that SRAP-based markers could be useful in detailed genotyping of $F$. culmorum isolates with different characteristics such as geographic region, host type and mating type. 


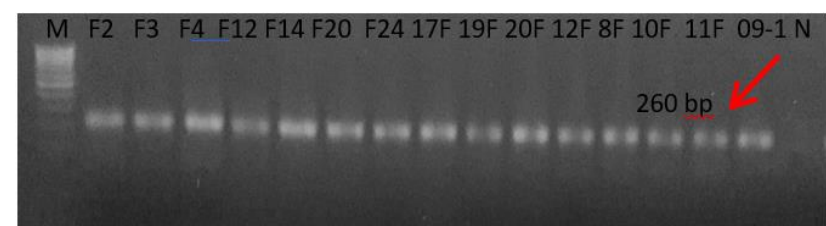

Figure 1 Mat1-2 profile of $F$. culmorum isolates. M: 100 bp DNA size marker (Thermo, USA), N: no template control

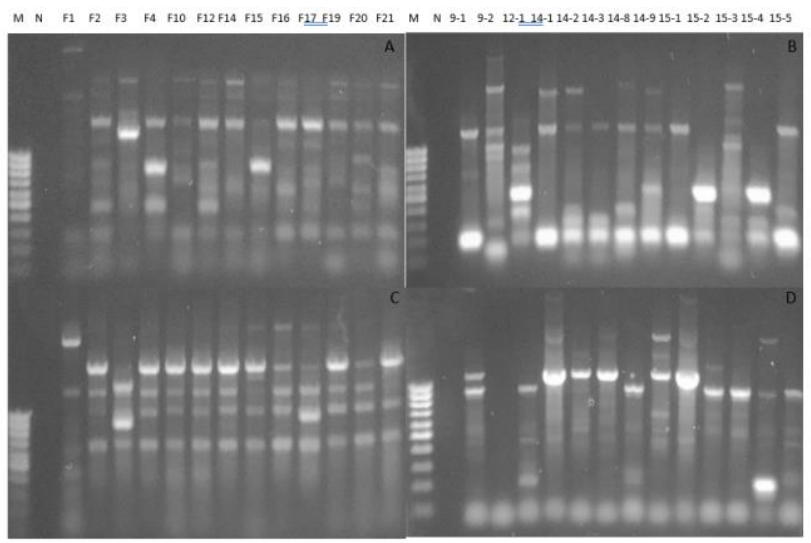

Figure 2 SRAP profiles of isolates by ME5/EM6 (A), ME5/EM1(B), ME1/EM3 (C), ME1/EM6 (D) M: 100 bp DNA markers, N: negative control

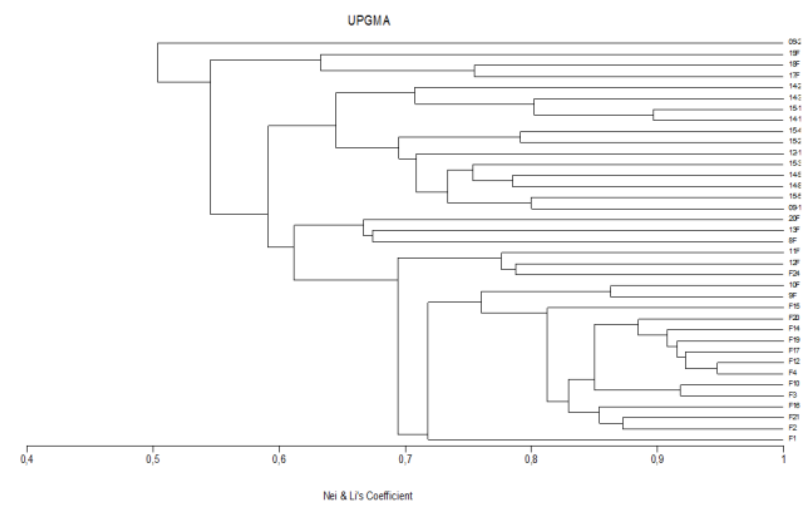

Figure 3 Dendogram showing genetic relatedness among F. culmorum isolates based on SRAP analysis

\section{Conclusion}

In this study, $F$. culmorum isolates, collected from diseased wheat and barley samples in different agroecological regions of Turkey, were subjected to genotyping analysis via mating type and SRAP markers. Findings obtained from both assays showed that isolates with similar and/or same characteristics investigated in this study were co-clustered in UPGMA-dendogram. Isolates with similar profiles could be evaluated in terms of practicing the similar disease control strategies. In this regard, SRAP based genotyping provide fast, reliable and reproducible results for detailed characterization of phytopathogenic isolates. 12 band per primer set was obtained from SRAP analysis which could be accepted as high level of polymorphism profile for a single primer set. Since genetic characterization of the quarantined phytopathogenic species $F$. culmorum is crucial in fight with HB and RR diseases, powerful tools to determine the genotypic variation among $F$. culmorum isolates are needed. SRAP results distinguished isolates according to their several important traits in this study. However further studies, including higher number of isolates and characteristics such as region and host type, should be carried out to get more knowledge about comprehensive genetic characteristics of this phytopathogenic species.

\section{Acknowledgement}

This study was supported by the Board of Regents of Istanbul Yeni Yüzyil University and TÜBİTAK 1090476 and 1110835 numbered projects.

\section{References}

Arslan Ü, Baykal N. 2002. Kök ve kökboğazı fungal patojenlerine karşı bazı buğday çeșitlerinin reaksiyonları ve tohum koruyucu fungusitlerin Fusarium culmorum (w.g.sm.) sacc.'a etkisi. "Uludag Üniv. Ziraat Fak. Derg., 16: 69-76.

Albayrak G, Yörük E, Gazdağlı A, Sharifnabi B. 2016. Genetic Diversity Among $F$. graminearum and $F$. culmorum Isolates Based on ISSR Markers. Arch. Biol. Sci., 68(2): 333-343. DOI: $10.2298 / \mathrm{ABS} 150630025 \mathrm{~A}$

Çepni E, Tunalı B, Gürel F. 2013. Genetic diversity and mating types of Fusarium culmorum and Fusarium graminearum originating from different agro-ecological regions in Turkey. J. Basic Microbiol., 53: 686-694. DOI:10.1002/jobm.201200066.

Desjardins AE, Proctor RH. 2007. Molecular biology of Fusarium mycotoxins. Int. J. Food Microbiol., 119: 47-50. DOI:10.1016/j.ijfoodmicro.2007.07.024.

Gürel F, Albayrak G, Diken O, Cepni E, Tunali B. 2010. Use of REP-PCR for genetic diversity analysis in Fusarium culmorum. J. Phytopathol., 158: 387-389. DOI: 10.1111/j.14390434.2009.01630.x.

Irzykowska L, Bocianowski J, Baturo-Cieśniewska A. 2013. Association of mating-type with mycelium growth rate and genetic variability of Fusarium culmorum. Cent. Eur. J. Biol., 8(7): 701-711. DOI: 10.2478/s11535-013-0176-3.

Kerényi Z, Moretti A, Waalwijk C, Olah B, Hornok L. 2004 Mating type sequences in asexually reproducing Fusarium species. Appl. Environ. Microbiol., 70: 4419-4423. DOI: 10.1128/AEM.70.8.4419-4423.2004.

Li G, Quiros CF. 2001. Sequence-related amplified polymorphism (SRAP), a new marker system based on a simple PCR reaction: its application to mapping and gene tagging in Brassica. Theor. Appl. Genet., 103: 455-461. DOI: 10.1007/s001220100570.

Mahmoud AF. 2016. Genetic Variation and Biological Control of Fusarium graminearum Isolated from Wheat in Assiut-Egypt. $\begin{array}{llll}\text { Plant } & \text { Pathol. } & \text { J., } & 32(2):\end{array}$ DOI:10.5423/PPJ.OA.09.2015.0201.

Miedaner T, Schilling AG, Geiger HH. 2001. Molecular genetic diversity and variation for aggressiveness in populations of Fusarium graminearum and Fusarium culmorum sampled from wheat fields in different countries. J. Phytopathol., 149: 641648. DOI: 10.1046/j.1439-0434.2001.00687.x.

Miedaner T, Cumagun CJR, Chakraborty S. 2008. Population genetics of three important head blight pathogens Fusarium graminearum, F. pseudograminearum and F. culmorum. Plant Pathol. J., 156: 129-139. DOI: 10.1111/j.14390434.2007.01394.x.

Niu C, Kebede H, Auld DL, Woodward JE, Burow G, Wright RJ. 2008. A safe inexpensive method to isolate high quality plant and fungal DNA in an open laboratory environment. Afr. J. Biotechnol., 7(16): 2818-2822.

Obanor F, Erginbas-Orakci G, Tunali B, Nicol JM, Chakraborty S. 2010. Fusarium culmorum is a single phylogenetic species based on multilocus sequence analysis. Fungal Biol., 114: $753-$ 765. DOI: 10.1016/j.funbio.2010.07.001

Pasquali M, Beyer M, Logrieco A, Audenaert K, Balmas V, Basler R, Boutigny AL, Chrpová J et al. 2016. A European Database of Fusarium graminearum and $F$. culmorum Trichothecene Genotypes. Front. Microbiol., 7: 1-11. DOI: 10.3389/fmicb.2016.00406. 
Smiley RW, Gourlie JA, Easley SA, Patterson LM. 2005. Pathogenicity of fungi associated with the wheat crown rot complex in Oregon and Washington. Plant Dis., 89: 949-957. DOI: 10.1094/PD-89-0949.

Scherm B, Orru M, Balmas V, Spanu F, Azara E, Delogu G, Hammond TM, Keller NP, Migheli Q. 2011. Altered trichothecene biosynthesis in TRI6-silenced transformants of Fusarium culmorum influences the severity of crown and foot rot on durum wheat seedlings. Mol. Plant Pathol., 12(8): 759771. DOI: 10.1111/J.1364-3703.2011.00709.X.

Wisniewska H, Kowalczyk K. 2005. Resistance of cultivars and breeding lines of spring wheat to Fusarium culmorum and powdery mildew. J. Appl. Genet., 46(1): 35-40.
Yörük E, Tunali B, Kansu B, Olmez F, Uz G, Zümrüt IM, Sarikaya A, Meyva G. 2016. Characterization of high-level deoxynivalenol producer Fusarium graminearum and $F$. culmorum isolates caused head blight and crown rot diseases in Turkey. J. Plant Dis. Protect., 123: 177-186. DOI: 10.1007/s41348-016-0027-y.

Zhang Xu, Hong-xiang M, Yong-jin Z, Jin-cheng X, Jian-hua C, Gui-hong Y, Xiao-bo S, Lei W. 2014. Identification and Genetic Division of Fusarium graminearum and Fusarium asiaticum by Species-Specific SCAR Markers. J. Phytopathol., 162: 81-88. DOI: 10.1111/jph.12155. 